\title{
Fifth Framework Programme: European Commission Announces R\&D Priorities
}

The European Union's Fifth Framework Programme for research and development for 1999-2003 should differ markedly from previous programmes in three main respects. First, Community research will pursue social and economic objectives more in keeping with citizen's concerns; second, efforts will be focused on a limited number of themes; and third, the application of research results and innovations will be emphasised. This in substance is the message set out in the European Commission's working document on the scientific and technological objectives of the Fifth Programme.

This document is the precursor to the formal proposal that the Commission will present within the next couple of weeks. The financial details have not yet been settled. However, the scientific themes and objectives supported by the Commission have already been determined.

European Commissioner Edith Cresson spoke out in favour of a reform of EU decision-making procedures in adopting the R\&D Pramework Programme (see the Davignon recommendation EN 28/2 1997), advocating a majority voting procedure within Council. "It is obvious that the situation needs correcting, and in depth", she said, "the first thing to do being the introduction, in the Intergovernmental Conference, of the principle of adopting the Framework Programme through a qualified majority". Mrs. Cresson believes that there are too many approval and control procedures, "meaning that we are prevented from reacting rapidly to unexpected needs, as seen recently in the mad cow crisis".

The European Commission proposes structuring the Fifth Framework Programme into six specific parts: - three thematic programmes; - discovery of living resources and ecosystems;
- development of a user-friendly information society; - promotion of competitive and sustainable growth;

- affirmation of the international role of European research;

- innovation and participation by small and medium-sized enterprises (SMEs); - development of human potential.

The general objective of the "living resources and ecosystem" programme is to maintain and improve European citizen's quality of life and the environment in Europe. Six key actions are planned: - Food and health: development of knowledge, technologies and methods for the production of a safe, healthy, balanced and varied food supply.

- Control of viral and infectious diseases: this action encompasses prion-caused diseases, modern "scourges" and AIDS research.

- The cellular factory: concerns the European market for products derived from biotechnology, expected to be worth 100 bn ecu by the year 2000.

- Water quality and management: covers technologies for water treatment and purification and the supply to arid and semi-arid regions.

- Environment and health: issues such as health effects of air pollution, heavy metals and toxic substances and electromagnetic radiation.

- New rural and marine technologies: innovation in agriculture and fisheries.

\section{The international role of European} research

Scientific and technological cooperation with third country research is envisaged, with the understanding that such arrangements could result in substantial mutual benefits. These activities would be conducted under Cooperation Agreements. Three types of international cooperation are provided for:

- Specific activities unable to be conducted within the framework of other (thematic) programmes. These would involve Central and Eastern European countries with which the EU does not have cooperation agreements, Mediterranean third countries and countries with "emerging" economies, addressing these countries' specific problems.

- Researcher training: a system of grants would be established to enable young scientists from third countries to work on Framework Programme projects in European laboratories.

- Coordination: with COST, Eureka and other European scientific cooperation bodies. Innovation and participation by SMEs.

The different thematic programmes include mechanisms for facilitating participation by SMEs and promoting innovation in Europe, including: - mechanisms facilitating the use, financing and transfer of the results and technologies produced by research, while protecting the required knowledge; - establishment of innovation agencies within programmes;

- creation of structured interfaces with funding bodies;

- introduction of networks to support innovation specific to the relevant research programmes and networking of firms innovating in the areas covered by the programmes;

- provision of opportunities for SMEs without research facilities to delegate their research tasks to outside agents;

- granting of exploratory bonuses to SMEs to cover the cost of preparing documents.

Other mechanisms specific to this programme include:

- creation of a "single window" within the Commission to assess proposals drafted by SMEs;

- streamlining and coordination of networks providing information and assistance concerning the EU research and innovation activities;

- establishment of a service to provide assistance in relation to intellectual property rights and access to private funding.

\section{Cooperative research projects}

The cut-off date for submitting cooperative research proposals (under the Fourth Framework R\&D programme) has been set as April 8, 1998. Cooperative 
research is basically a system designed to boost the involvement of SMEs in Community research programmes. It enables SMEs to have access to the equipment needed to have research done for them by university laboratories or research centres, but to continue owning the results. This system was successfully tested under the BRITE-EURAM programme (industrial and materials technologies) and has been extended to other Framework 4 specific programmes. There is also assistance to cover the costs involved in seeking partners, launching feasibility studies, carrying out market research and putting together research proposals.

\section{Opinions...}

\section{ESC calls for review}

The EU's Economic and Social Committee (ESC) is urging the European Commission to do more than merely revamp the EU's R\&D Framework Prog-ramme and to table genuinely innovative proposals and medium and long-term objectives. The aim is to stop financial resources for research being spread too thinly and foster closer links between Community research, wider pan-European research and major R\&D projects that EU Member States would like to achieve together. The ESC is putting emphasis on the need to create a financial and tax environment that is conducive to intangible investment in research and training. It calls on the Commission to: - implement technologies and industrial assessment systems on a European scale; - adopt a "bottom up" approach and be more selective about choosing priority areas;

- promote the application of major strategic projects, with a series of measures for ensuring a geopolitical and economic balance as well as project cohesion.

\section{House of Lords Assessment}

The European Commission's (EC) Fifth Framework R\&D programme has been condemned as unfocused and allembracing by a cross-party parliamentary committee. The House of Lords science and technology committee was "astonished" by the breadth of the plans. Its report challenged the EC to "name one area of research which could not find a place in one of the categories". It called for a review to ensure that it added value to national research programmes. A report on Framework from a European Union panel of experts may address some of the concerns.

European added value was central to the report, which recommended that funding should focus on economically and socially relevant research. According to the panel, added value would come from developing large-scale research facilities which no single nation could sustain. It also recommended building internationally competitive research communities in areas such as IT and communications, and the creation of European industrial platforms based on common standards.

\section{And finally..}

A British newspaper report that a Belgian doctor may have accidentally created the first human "clone" was complete fantasy. Prof. Robert Schoysman, head of the fertility laboratory at the Van Helmont hospital in Vilvoorde, angrily rejected a Sunday Times report that the "clone", a four-year old twin boy, was produced by a technique developed to improve the success rate of fertility treatment. "This information is totally erroneous; it's nothing to do with cloning. It is a fantasy triggered by Dolly". Schoysman was referring to a sheep cloned in Britain.

Schoysman said that his laboratory practices in vitro fertilization, handling 800 cases a year, and takes a totally different approach. The laboratory uses a so-called hatching technique under which a frozen human embryo is thawed and the surrounding membrane rubbed to improve the chances of the egg escaping and becoming implanted in the mother's womb. "It can later divide and produce identical twins - nothing to do with cloning" he insisted. Schoysman said details of the technique were first published in 1993 in the British scientific journal "Human Reproduction". Cloning, which creates genetically identical individuals, can be done by splitting embryos or by transferring the nucleus of one cell into an egg - the technique used for Dolly. "We are not equipped to do that", he said, adding he doubted if the hospital's ethics' committee would accept cloning.

Access e.e.i.g., Belgium, and Reuters Ltd.

\section{The Executive's Soliloquy}

To spend, or not to spend: that is the question.

Whether 'tis wiser in the end to run

The risks and dangers of an outmoded plant;

Or to risk funds to buy updated equipment,

And thus seeking survival? To spend; to risk;

No more: and by so risking seek to find

The profits and the improved bottom line

Shareholders love so; 'tis an expenditure

Cautiously to be made. To spend; to risk;

To risk, perchance to fail; Ay, there's the rub:

For in those flops of man what threats may

come

To undermine the corporate leader's role,

Must give us pause. There's the respect

That makes calamity of corporate life.

For who would bear the ills that failure brings.

The questions posed, the treasurer's sad report,

The pangs of indecision, the sleepless nights,

Inflation's cutting edges, and the loss

When corporate trappings no longer reign

supreme,

When he himself might his quietus make

By resignation? - Who would worry stop,

To grunt and sweat under a weary load,

But that the dread of something different,

That undiscovered country from whose bourn

No executive returns, puzzles the will,

And makes us rather hold that which we have

Than to fly to changes that we know not of?

Thus status quo makes heroes of us all;

And the old sanctity of corporate wisdom

Avoids attack from the pale cast of thought.

And all shareholders and boards of directors

With this regard their questions turn awry

And we win to play again.

From Mumblepeg(c),

published by the International Association

of Professional Bureaucrats 